\title{
Religion Wise Response to Polio Eradication Programme Imposed by Government on the Respondents: A Case Study of Aligarh District
}

\author{
Author Details: \\ Dr. Abhimanyu kumar, Assistant Prof. Sociology, Govt. P.G. College, Ranikhet
}

Abstract

This research paper is made to examine the views of the people of modern India which is based on empirical research. The present research is based on a good deal of primary and secondary data obtained from respondent's demographic characteristic i.e. age, sex, caste, education, family type income and occupation in relation to polio eradication programme (PEP) applied on them. The research data is collected by preparing a schedule through stratified sampling method. An interview schedule was prepared and was applied to 600 respondents in which 300 belonged to urban areas and rest 300 respondents belonged to rural areas. The area of the sample is District Aligarh of Uttar Pradesh state of India.

Key wards: - Polio, respondent, demographic factors, paralysis and disease

\section{Introduction:}

The words Polio (grey) and Myelon (marrow, indicating the spinal cord) are derived from the Greek. It is effect of poliomyelitis virus on the spinal cord that leads to the classic manifestation, Paralysis, (Andersen, R., 19790) ${ }^{1}$ Although records from antiquity mention crippling diseases compatible with poliomyelitis, it was Michael Underwood from England, in 1789, first described disability of the lower extremities in children that was recognizable as poliomyelitis, (Alwin, D, 1975) ${ }^{2}$. The first outbreaks in Europe were reported in the early 19th century, and outbreaks were reported in

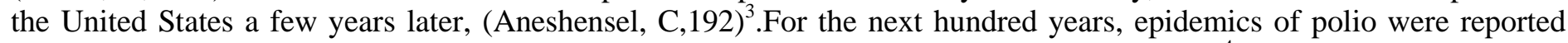
from developed countries in the northern hemisphere each summer and fall,( Aylward, B,1997) ${ }^{4}$.These epidemics became increasingly severe, and the average age of persons affected rose. The increased age of primary infection increased both the disease severity and number of deaths from polio. Polio reached a peak in the United States in 1952, with more than 21,000 paralytic cases, (Berg, M, 1992) ${ }^{5}$. Polio incidence fell rapidly following introduction of effective vaccines. The last case of wild-virus polio acquired in the United States was in 1979, and global polio eradication may be achieved within the next decade. Polio is a disease caused by a virus. It enters a child's (or adult's) body through the mouth,(Johnson, Allan,1995) ${ }^{6}$.Sometimes it doesn't cause serious illness. But sometimes it cause paralysis (can't move arm or leg). It may be possible to kill people who get it, usually by paralyzing the muscles. The four types of polio are:-Bulbar polio, Cerebral poliomyelitis, non-paralytic polio and Paralytic polio, (Dobrowolsky, D, 1999) ${ }^{7}$.

A study was undertaken on 500 children under the age of 5 years belonging to a low income group. All were attending the pediatrics outpatient department of a large teaching hospital in New Delhi, India. Only 25\% were found to have received complete primary immunization as per the National Immunization Schedule (bacille Calmette- Guerin at birth, three doses of diphtheria, pertussis and tetanus and oral poliovirus vaccine at 6,10 and 14 weeks and measles vaccine at 9 months). The major reasons for non-immunization of the children were: migration to a native village (26.4\%); domestic problems (9.6\%); the immunization centre was located too far from their home $(9.6 \%)$; and the child was unwell when the vaccination was due $(9 \%)$. Twelve percent of mothers could not give any reason for non-immunization. In addition to the migration of children to rural areas, the other significant finding was an indirect effect of intensive OPV administration as part of polio eradication initiative. The lack of awareness and fear of side effects constituted a small minority of reasons for non-immunization. (Mathew JL, Babbar H, Yadav S., 2002) ${ }^{8}$.

A survey was conducted at an Integrated Child Development Services (ICDS) Scheme project in North Calcutta among 656 mothers having children less than 3 years of age to assess their perception and practice regarding pulse polio immunization (PPI). It was revealed that $91.8 \%$ of under 3-years children received PPI on 9-12-1995 and 94.4\% on 20-11996. Major reasons for not accepting the services on those two days included 'mothers unaware' (22\%), 'child too small' $(30.5 \%)$, etc. Major source of first information was television (TV)/radio (57.2\%) followed by anganwadi workers (AWWs) (33.8\%). However, majority of the mothers were finally motivated for PPI by AWWs (58.8\%) followed by the role of TV/radio (34.1\%). Although 70.7\% mothers knew the name of the vaccine correctly, only 3.5\% mothers could tell the exact purpose of its administration. Most mothers (73\%) opined that 2 drops of oral polio vaccine (OPV) was administered to their children and only $14.6 \%$ hoped that the Government in future will conduct such programmes. The 
average waiting time of mothers at immunization centres were found to be 7.2 minutes, (Taylor, CE, Cults, T., Taylor, M $1997)^{9}$.

India is contributing large number of total world's polio cases. The present study was carried out with the objective to assess the knowledge of the parents regarding pulse polio and their perception towards pulse polio and other immunization. The study revealed that children of all age groups participated in PPI though the coverage was low in $37-$ 48 and 49-60 month age group. In all 30.5\% children of respondents could not get OPV in the previous year and they came for the first time to the PPI centre. A significant finding of the study was the status of children regarding other immunization, as $59.5 \%$ of the respondents were not immunizing their children for other vaccines. In the present study, $73.2 \%$ of the respondents could tell correctly about pulse polio. Predominant source of information about pulse polio was found to be electronic media $(55.8 \%)$ followed by health workers $(20.9 \%)$. Only $8.4 \%$ respondents to identify the reasons for non-immunization/postponing immunization, parents of 615 poliomyelitis (APM) children and 908 children attending the Outpatient Department (OPD) for other ailments opined that distance of PPI centre was far away from their residence, (Rasania SK, Sachdev T, 2003) ${ }^{10}$.

Objective under study: - To study the demographic factors of the parents living in the rural and urban areas and difference of opinion of Hindu and Muslim parents towards polio eradication programme.

Null Hypothesis (Ho): There is no significant difference of response of religion wise rural and urban parents to Polio eradication programme.

\section{Research methodology:-}

A systematic methodology is an important step to any research because it directly influences the validity of the research findings. This precisely describes the methodology tools and instruments adopted in conducting the research.

\section{Area of Under Study}

Aligarh district is a part of Central Ganga Plain of the state covering of 5498 sq. Km. and lies between North latitudes 27 o 28 and 28 o 10 and East longitudes 77 o 29 and 78 o 36 with total population of 4,32,37,60 as per 2001 census (density: $786 \mathrm{person} / \mathrm{sq} . \mathrm{Km}$.). The district is bounded by impossible for the investigator to carry out his or her research. Programme for the entire population. So the usual procedure was adopted which was adopt which was to select a sample from the population to be studied and to carry out the research on the sample.

Sample under study: - A sample of 600 respondents was taken in which 300 belonged to urban areas and rest 300 respondents belonged to rural areas. Again 300 respondents of urban area were equally divided into 150 hindu and 150 muslim parents. In the same way 300 respondents of rural area was equally divided into 150 hindu and 150 muslim parents.

Collection of data: - Hindi version of the scales was used as per the convenience of the respondents. Each subject was given interview schedule individually for limited time and was asked to fill it under the strict supervision of the researcher.

Statistical analysis of data: - The collected data was classified and tabulated in accordance with the objectives to drive the meaningful and relevant inferences. The data was analyzed by using statistical techniques like frequency, percentage, mean and $\chi^{2}$ (chi-square) test

Table No. 1.Sex wise distribution of respondents related to PEP

\begin{tabular}{|l|c|c|c|c|c|c|}
\hline Sex & \multicolumn{2}{|c|}{ Hindu respondents } & \multicolumn{2}{c|}{ Muslim respondents } & \multicolumn{2}{c|}{ Total } \\
\hline Male & 161 & $(53.6)^{*}$ & 121 & $(4.3)^{* *}$ & 282 & $(47.00)$ \\
\hline Female & 139 & $(46.4)^{*}$ & 179 & $(39.7)^{* *}$ & 318 & $(53.00)$ \\
\hline Total & \multicolumn{2}{|c|}{$\mathbf{3 0 0}$} & \multicolumn{2}{|c|}{$\mathbf{3 0 0}$} & $\mathbf{6 0 0}$ \\
\hline
\end{tabular}

*, * Percentage Male Hindu \& Male Female Hindu, **, ** Percentage of Male Muslim \& Male Female Muslim 
It can be again analysis with help of table shows that sex wise distribution of respondent related to PEP. The respondent has been categorized between male and female in a row it is further divided between Hindu and Muslim if we calculated them in row the respondents of Hindu family (Male) is 161(53.6) while 121 (4.3) of Muslim family (male) leading to its total $282(47.00)$ at the another hand in case of female respondents 139(46.4) are related with Hindu family while 179 related with Muslim family leading total 318(53.00), while the total value number of male \& female are 600 . The number of female respondents is more than male respondents $(318>282)$ either we calculated them in row or column the total value of respondents is equal.

Table No. 2.Age wise distribution of respondents related to PEP

\begin{tabular}{|l|c|c|c|}
\hline Age group & Male Respondents & Female Respondents & Total \\
\hline Below 45 years & $233(82.3)^{*}$ & $298(94.0)^{* *}$ & $531(88.5)$ \\
\hline 45 to 55 years & $32(11.3)^{*}$ & $17(5.4)^{* *}$ & $49(8.2)$ \\
\hline More than 55 year & $18(6.4)^{*}$ & $2(.6)^{* *}$ & $20(3.3)$ \\
\hline Total & $\mathbf{2 8 3 ( 4 7 . 2 )}$ & $\mathbf{3 1 7}(\mathbf{5 2 . 8})$ & $\mathbf{6 0 0}(\mathbf{1 0 0})$ \\
\hline
\end{tabular}

* Percentage of Male respondent, ** Percentage of Female respondent

In this table we have measured the number of respondent related with three age groups. The age group has also divided between male as well as female respondents 45 year age has been as well as an average (median) in the number of male respondents below 45 years age 233 (82.3) while 298(94.0) is related with female respondent, leading to its total member of respondent as well as them $531(88.5)$ at the another hand we have measured the age group above 45 to 55 year in which male respondent are 32 (11.3) while 17 (5.4) is related leading to its total number of respondent as well as its 49 (8.2) in the next column we have measured the age group which is more than 55 years in which the number of male respondent is 18 (6.4) while it is 2(.6) related with female respondent, leading to its total value as well as20 (3.3) if we calculated its value through a column in case of male respondent it is 283 (47.2) while in case of female 317 (52.8).

But the total value both of them male as well as female respondent is equal to 600. Again it is true observation that the number of female respondent is greater than the male respondent [317 (52.8) > 283 (47.2)]

Table No. 3.Religion wise distribution of respondents related to PEP

\begin{tabular}{|l|c|c|c|}
\hline Religion & $\begin{array}{c}\text { Males } \\
\text { Respondents }\end{array}$ & $\begin{array}{c}\text { Females } \\
\text { Respondents }\end{array}$ & Total as \\
\hline Hindu & $162(57.2)^{*}$ & $138(43.5)^{* *}$ & $300(50)$ \\
\hline Muslims & $121(42.8)^{*}$ & $179(56.5)^{* *}$ & $300(50)$ \\
\hline Total & $\mathbf{2 8 3}(\mathbf{4 7 . 2})$ & $\mathbf{3 1 7}(\mathbf{5 2 . 8})$ & $\mathbf{6 0 0}(\mathbf{1 0 0})$ \\
\hline
\end{tabular}

*Percentage of all males falls among every religions category, **Percentage of females fall among every religion categories

This table is categorized on the basis of religion respondents this variables (religion) is further makes the distinction between Hindu respondent and Muslim, as well as males and females in a row the number of Hindu Males respondents is 162(57.2) while 138 (43.5) is in case of female respondents, leading to its total value 300(50). At another hand in case of Muslim respondents, 121(42.8) is related with males, while 179(56.5) is in case of female respondents, leading to its total value 300(50). If calculate it value through a column in case of male it is 283(47.2) while in case of female (Hindu and Muslim) it is 317(52.8), leading to its total value 600(100).

We analyze have the given table the number of female respondents as well as these percentage ratios is more than male respondents $[317(52.8)>283(47.2)]$. 
Impact Factor 3.582 Case Studies Journal ISSN (2305-509X) - Volume 7, Issue 3-Mar-2018

Table No. 4.Caste wise distribution of respondents related to PEP

\begin{tabular}{|l|c|c|c|c|c|c|}
\hline Caste groups & \multicolumn{2}{|c|}{ No of respondents Hindu } & \multicolumn{2}{|c|}{$\begin{array}{c}\text { No of respondents } \\
\text { Muslim }\end{array}$} & \multicolumn{2}{c|}{ Total } \\
\hline Upper caste (Gen) & 98 & $(32.6)^{*}$ & 212 & $(70.6)^{* *}$ & 310 & $(51.6)$ \\
\hline Middle Caste (OBC) & 65 & $(21.6)^{*}$ & 70 & $(23.4)^{* *}$ & 135 & $(22.5)$ \\
\hline Lower Caste (SC) & 137 & $(45.7)^{*}$ & 18 & $(6.0)^{* *}$ & 155 & $(25.8)$ \\
\hline Total & \multicolumn{2}{|c|}{300} & \multicolumn{2}{|c|}{300} & \multicolumn{2}{|c|}{600} \\
\hline
\end{tabular}

*Percentage of All Hindu respondents, **Percentage All Muslim respondent

This table makes an analysis by keeping a caste variable in which caste is categorized among three groups in upper caste, middle caste and lower caste. It also analyze community related respondents Hindu as well as Muslim in a row the number of upper caste related with Hindu respondent is 98(32.7) while in case of Muslim respondents it is 212(70.6), leading to its total value 310(51.6). In case of middle caste the number of respondents related with Hindu is 65(21.6), while it is 70 (23.4), in case of Muslim respondents leading to its total value 135(22.5). In case of lower caste in the number of Hindu respondents is 137(45.7), while it is 18(6.0) in case of Muslim respondents, leading to its total value $155(25.8)$ the table is calculated either row or through a column the result related with total value is same. But in case of upper caste as well as middle caste the number of Muslim respondents is more than Hindu respondents. In case of Hindu [212 (70.6) > 98 (32.7)].In case of Muslim [70 (23.4) > 65 (21.6)]

Table No.5.Education wise distribution of respondents related to PEP.

\begin{tabular}{|c|c|c|c|c|c|}
\hline Education Group & $\begin{array}{c}\text { Hindu Male } \\
\text { Respondents }\end{array}$ & $\begin{array}{c}\text { Hindu Female } \\
\text { Respondents }\end{array}$ & $\begin{array}{c}\text { Muslim Male } \\
\text { Respondents }\end{array}$ & $\begin{array}{c}\text { Muslim Female } \\
\text { Respondents }\end{array}$ & Total \\
\hline Illiterate & $48(29.6)^{*}$ & $78(56.5)^{* *}$ & $58(47.9) * * *$ & $146(81.6) * * * *$ \\
\hline Up to 10th Std. & $68(42.0)^{*}$ & $35(25.4)^{* *}$ & $35(28.9)^{* * *}$ & $19(10.6) * * * *$ & $157(26.2)$ \\
\hline Up to 12th Std. & $15(9.3)^{*}$ & $06(4.3)^{* *}$ & $13(10.7)^{* * *}$ & $05(2.8) * * * *$ & $39(6.5)$ \\
\hline B.A. \& M.A. & $17(10.5)^{*}$ & $11(8.0)^{* *}$ & $06(4.9)^{* * *}$ & $04(2.2) * * * *$ & $38(6.3)$ \\
\hline $\begin{array}{l}\text { M.Phil,. Ph.D., } \\
\text { M.Ed. etc. }\end{array}$ & $14(8.6)^{*}$ & $08(5.8)^{* *}$ & $09(7.4)^{* * *}$ & $05(2.8) * * * *$ & $36(6.0)$ \\
\hline Total & $\mathbf{1 6 2 ( 1 0 0 )}$ & $\mathbf{1 3 8 ( 1 0 0 )}$ & $\mathbf{1 2 1}(\mathbf{1 0 0})$ & $\mathbf{1 7 9 ( 1 0 0 )}$ \\
\hline
\end{tabular}

*, **Percentage of Hindu male Hindu females, ***, **** Percentage of Muslim male \& Muslim female

The above table shows that in illiterate group in case of Hindu there are 48 (29.6) males respondents and 78 (56.5) females respondents in Muslim, there are 58 (47.9) males' respondents' 146 (81.6), females respondents overall there 330 (55) respondents in this group. In case of 10th standard in Hindu there are 68(42) males respondents and 35 (25.4) females respondents. In Muslims there are 35 (28.9) males respondents and 19 (10.61) females respondents. Overall there are 157 (26.2) respondents in this group in case of $12^{\text {th }}$ standard. In Hindu there are 15 (9.35) males respondents and 6 (4.3) females respondents. In Muslims there are 13 (10.7) males respondents and 5 (2.8) females respondents over all there are 39 (6.5) respondents in this group in case of higher education in Hindu there are 17 (10.5) males respondents and 11(8.0) females while in case of Muslim there are 6(4.9) males respondents and 4(2.2) females respondents overall there are 38 (6.3) respondents in this group. In the other group in Hindu there are 14 (8.6) males respondents and 8 (5.8) females respondents. In Muslims there are 9 (7.4) males respondents and 5 (2.8) females respondents. Over all there are 36 (6\%) respondents in this group.In analyzing related in Hindus as well as Muslims respondent shows that the number of illiterate respondents is greater than else. It is a reverse in case. [330(55)>157(26.2) 39(6.5)>, 38(6.3)> $36(6.0)$ ] 
Impact Factor 3.582 Case Studies Journal ISSN (2305-509X) - Volume 7, Issue 3-Mar-2018

Table No .6. Family wise Distribution of respondents related to PEP.

\begin{tabular}{|l|c|c|c|c|c|c|}
\hline Family & \multicolumn{2}{|c|}{ Number of Hindu respondents } & \multicolumn{2}{|c|}{ Number of Muslim respondents } & Total & \\
\hline Nuclear & 203 & $(67.6)^{*}$ & 228 & $(76.0)^{* *}$ & 431 & $(71.8)$ \\
\hline Joint & 97 & $(32.3)^{*}$ & 72 & $(24.0)^{* *}$ & 169 & $(28.2)$ \\
\hline Total & \multicolumn{2}{|c|}{300} & \multicolumn{2}{|c|}{300} & \multicolumn{2}{|c|}{$\mathbf{6 0 0}$} \\
\hline
\end{tabular}

\section{* Percentage of all Hindu respondents, ** Percentage of all Muslim respondents}

This table has been divided the family respondents in two part nuclear family as well as joint family, Hindu respondent's as well Muslim respondents. The number of nuclear family related to Hindu is 203 (67.6) but it is 228 (76.0), in case of Muslim respondents leading to its total value as well as 431(71.8) at the another hand the number of Hindu respondent in case of joint family is 97 (32.3) while it is 72 (24.0), in case of Muslim respondents leading to 169(28.2) the total value of both is same either in a column or in a row but the number as well as related with Muslim respondents is more than joint family. [431 (71.8) > 169 (28.2)]

Table No.7.The numbers of family members wise distribution of respondents related to PEP.

\begin{tabular}{|c|c|c|c|c|c|c|}
\hline $\begin{array}{c}\text { Number of family } \\
\text { Members }\end{array}$ & \multicolumn{2}{|c|}{ Hindu Respondent } & \multicolumn{3}{c|}{ Muslim Respondent } & \multicolumn{2}{c|}{ Total } \\
\hline $2-7$ & 184 & $(61.3)^{* *}$ & 151 & $(50.3)^{* *}$ & 335 & $(55.8)$ \\
\hline $8-13$ & 88 & $(29.3)^{*}$ & 107 & $(33.7)^{* *}$ & 195 & $(32.5)$ \\
\hline $14-19$ & 20 & $(6.7)^{*}$ & 29 & $(9.7) * *$ & 49 & $(8.2)$ \\
\hline $20-25$ & 4 & $(1.3)^{*}$ & 11 & $(3.7)^{* *}$ & 15 & $(2.5)$ \\
\hline 26 above & 4 & $(1.3)^{*}$ & 2 & $(0.7)^{* *}$ & 6 & $(1.0)$ \\
\hline Total & \multicolumn{3}{|c|}{$\mathbf{3 0 0}(\mathbf{1 0 0})$} & $\mathbf{3 0 0}(\mathbf{1 0 0})$ & & $\mathbf{6 0 0}$ \\
\hline
\end{tabular}

*Percentage of all Hindu respondents, **

Percentage of all Muslim respondents

This table analysis on the basis of family members which are divided in five classes Hindu respondent as well as Muslim respondent this first group has its limit 2-7 in which 184 (61.3) Hindu respondents while 151 (50.3) in case of Muslim respondents leading to its total value 335(55.8), 8-13 in this group the number of Hindu respondents is 88 (29.3) in case of Muslim respondents 107(33.7), leading to its total value 195 (32.5), 14-19 the number of Hindu respondents in case of this group is 20(6.71) while 29(9.7) in case of Muslim respondents leading to its total value 49 (8.2), 20-25 the number of Hindu respondents 4 (1.3), in case of Muslim respondents 11 (3.7) leading to its total value 15 (2.5), above 26 the number of Hindu respondent is 4 (1.3) while it is $2(0.7)$ in case of Muslim respondents leading to its total value 6 (1.0), the total value of the given table is same. It is also reverse case so far as be increasing the number of family member by and by the total value decrease

Table No .8. Occupation wise distribution of respondents related to PEP

\begin{tabular}{|c|c|c|c|c|c|c|c|c|c|c|}
\hline Occupation & \multicolumn{2}{|c|}{$\begin{array}{l}\text { Hindu Male } \\
\text { Respondents }\end{array}$} & \multicolumn{2}{|c|}{$\begin{array}{c}\text { Hindu Female } \\
\text { Respondents }\end{array}$} & \multicolumn{2}{|c|}{$\begin{array}{l}\text { Muslim Male } \\
\text { Respondents }\end{array}$} & \multicolumn{2}{|c|}{$\begin{array}{l}\text { Muslim Female } \\
\text { Respondents }\end{array}$} & \multicolumn{2}{|c|}{ Total } \\
\hline Public sector & 45 & $(27.8)^{*}$ & 27 & $(167)^{* *}$ & 22 & $(18.2)^{* * *}$ & 18 & $(10.1)^{* * * *}$ & 112 & (8.7) \\
\hline Private Sector & 12 & $(7.4)^{*}$ & 12 & $(7.4)^{* *}$ & 18 & $(14.9)^{* * *}$ & 31 & $(17.3)^{* * * *}$ & 73 & $(12.2)$ \\
\hline Labour classes & 60 & $(37.0)^{*}$ & 46 & $(28.4)^{* *}$ & 54 & $(44.6)^{* * *}$ & 69 & $(38.5) * * * *$ & 229 & $(38.2)$ \\
\hline Businessmen & 20 & $(12.3)^{*}$ & 32 & $(23.2)^{* *}$ & 19 & $(15.7)^{* * *}$ & 47 & $(26.3)^{* * * *}$ & 118 & (19.7) \\
\hline House Wife & & 00 & 21 & $(15.2)^{* *}$ & 00 & 00 & 14 & $(7.8) * * * *$ & 35 & $(5.8)$ \\
\hline Agriculture & 25 & $(15.4)^{*}$ & 00 & 00 & 8 & $(6.6)^{* * *}$ & 00 & 00 & 33 & $(5.5)$ \\
\hline Total & \multicolumn{2}{|c|}{$162(100)$} & \multicolumn{2}{|c|}{$138(100)$} & \multicolumn{2}{|c|}{$121(100)$} & & 179 (100) & \multicolumn{2}{|c|}{$600(100)$} \\
\hline
\end{tabular}




\section{*, ** Percentage of all Hindu Respondent, ***, **** Percentage of all Muslim Respondent}

The above table shows that the Public sector groups total is 112 (18.7) respondents in Hindu there are 45 (27.8), males and 27 (16.7) females respondents and in Muslim there are 22 (18.2) males, 18(10.1) females respondents, in the private sector group is total 73 (12.2) respondents there are 12 (7.4) males respondents and 12 (7.4) females respondents in Muslim there are 18 (14.9) males 31 (17.3) females respondents, in the labour class the total value in 229 (38.2) respondents in Hindu there are 60 (37.0) males respondents and 46 (28.4) females respondents. In Muslim there are 54 (54.6) males, 69(38.5) females respondents. In the Business group of the total 118 (19.7) respondents, in case of Hindu there are 20 (12.3) males' respondents, 32(23.2) females respondents. In Muslim there are 19 total 35(5.8), In the House wife group of the total number 35(5.8) in Hindu there (not all) males respondent, 21(15.2) females respondent in the Muslim there are (not all) males respondents and 14 (7.8) females respondents, in the agriculture group of the total 33(55.5) respondents in Hindu there are 25(15.4) are males respondents and (not all) females respondents and in Muslim there are 8 (6.6) males respondents, (not all) females respondents.

Table No.9.Significance of difference between response of rural and urban parents to polio eradication programme (PEP)

\begin{tabular}{|c|c|c|c|c|c|c|}
\hline \multirow{2}{*}{ Area } & \multicolumn{7}{|c|}{ Responses } \\
\cline { 2 - 8 } & No Response & $\begin{array}{c}\text { Low } \\
\text { Response }\end{array}$ & $\begin{array}{c}\text { Average } \\
\text { Response }\end{array}$ & $\begin{array}{c}\text { High } \\
\text { Response }\end{array}$ & $\begin{array}{c}\text { Very high } \\
\text { Response }\end{array}$ & Total \\
\hline Urban & $\mathbf{5}$ & $\mathbf{6 2}$ & $\mathbf{1 3 2}$ & $\mathbf{1 0 1}$ & $\mathbf{0 0}$ & $\mathbf{3 0 0}$ \\
\hline Rural & $\mathbf{4}$ & $\mathbf{7 7}$ & $\mathbf{1 5 8}$ & $\mathbf{6 0}$ & $\mathbf{1}$ & $\mathbf{3 0 0}$ \\
\hline Total & 9 & 139 & 290 & 161 & 1 & 600 \\
\hline
\end{tabular}

$$
\begin{array}{ll}
\chi^{* 2} & =\quad 15.502 \chi_{\mathrm{t}}^{2}=9.488 \\
\chi^{*^{2}>\chi_{\mathrm{t}}^{2}} & \text { at } 5 \% \text { level of significance }
\end{array}
$$

Where $\chi^{*^{2}} \quad=\quad$ Computed value

$\chi_{\mathrm{t}}^{2} \quad=\quad$ Tabulate value / theoretical value

It can be seen that $\chi^{* 2}$ (Calculated) value has come out to be 15.502 but $\chi_{\mathrm{t}}^{2}$ (tabulated) value to be 9.488 since here calculated value is greater than to tabulated value $\left(\chi^{*^{2}>} \chi_{\mathrm{t}}{ }_{\mathrm{t}}\right.$. Which is significant at $5 \%$ level of confidence therefore null hypothesis is rejected.

In case of average responses areas related with urban is also lesser than rural areas $(132<158)$ as well as in case of high response the number of response related with urban areas is greater than rural areas $(101>60)$ while in case of very high response the number of responses related with urban areas perfectly inelastic it means zero. While in case of rural areas equal to 1 .

By analysis of the table, the number of responses is noted more in case of rural areas in comparison of urban areas. Yet number of responses has different values in different areas. If we calculated the values in a row is same in both urban areas as well as rural areas if we calculated the value by columns in urban areas as well as rural areas it will be the number of responses is 5 in case of urban areas while 4 in case of rural areas its total value equal to 9 . In case of low response 62 in a related urban areas and 77in a related to rural areas its total values 139. In case of average responses the number of responses related with urban areas is 132 while 158 related with rural areas. Its value is 290 . In case of high response number of responses relative with urban areas are 101. While, 60 related with rural areas. It total values 161 , testily in case of very high responses the numbers of responses are related with urban areas equal to zero. While in case of rural areas equal to 1 , its total value equal to 1 . 
Impact Factor 3.582 Case Studies Journal ISSN (2305-509X) - Volume 7, Issue 3-Mar-2018

Table 10. Significance of difference between response of Hindu and Muslim parents to PEP.

\begin{tabular}{|c|c|c|c|c|c|c|}
\hline \multirow{2}{*}{ Religion } & \multicolumn{7}{|c|}{ Responses } \\
\cline { 2 - 7 } & No Response & $\begin{array}{c}\text { Low } \\
\text { Response }\end{array}$ & $\begin{array}{c}\text { Average } \\
\text { Response }\end{array}$ & $\begin{array}{c}\text { High } \\
\text { Response }\end{array}$ & $\begin{array}{c}\text { Very high } \\
\text { Response }\end{array}$ & Total \\
\hline Hindu & $\mathbf{0 0}$ & $\mathbf{2 8}$ & $\mathbf{1 4 4}$ & $\mathbf{1 2 7}$ & $\mathbf{1}$ & $\mathbf{3 0 0}$ \\
\hline Muslim & $\mathbf{9}$ & $\mathbf{1 1 1}$ & $\mathbf{1 4 6}$ & $\mathbf{3 4}$ & $\mathbf{0 0}$ & $\mathbf{3 0 0}$ \\
\hline Total & 9 & 139 & 290 & 161 & 1 & 600 \\
\hline
\end{tabular}

(df.4)

$\chi^{*^{2}}=113.295 \chi_{\mathrm{t}}^{2}=9.488$

$\chi^{* 2}>\chi_{\mathrm{t}}^{2}$ at $5 \%$ level of significance

Where $\chi^{*^{2}} \quad=\quad$ Calculated value

$\chi_{\mathrm{t}}^{2} \quad=\quad$ Tabulated value

It can be seen that $\chi^{* 2}$ (calculated) value has come out to be 113.295 but $\chi_{\mathrm{t}}^{2}$ (tabulated) value to be 9.488 since here calculated value is greater than to tabulated value $\left(\chi^{*^{2}}>\chi_{t}^{2}\right)$ which is significance at $5 \%$ level of confidence therefore null hypothesis is rejected.

Interpretation of the table shows significance based in primary data we have observed mainly this table religion in which the findings are relative with Hindus as well as Muslims parents. The religion is respond by the interview schedule method mainly based on interviews and surveys responses is categories among five columns, number of responses, low responses, average response, high responses and very high responses. In Hindu religion the number of no response is zero, the number of low response 28, the number of average response 184, the number of high response 127 and in case of very high response is equal to 1 now the number of responses have observed also in case of Muslims religion the number of no response is 9 , in case of low response 111, while in case of average response 146, as well as in case of high responses 34 and in case of very high response is zero. By the closed observation we have noted that the number of no response in case of Hindu religion related with Hindus is also lesser then Muslims religion $(28<111)$. In case of average response the religion with relative Hindu lesser then Muslim religion $(144<146)$ as well as incase high response number of response relative with Hindu religion is greater than Muslim religion i.e. (127>34) while in case of very high response is number of response relative with Muslim religion perfectly in elastic it means, zero while in case of Hindu parents is equal to 1 . By analysis the table number of response are noted more in case of Hindu parents compare than Muslim parents. Although number of response has different value is different religion of we calculated value are row is same is both Hindu and Muslim religion but if we calculate the value by column Hindu as well as Muslim parents, while in case of Muslim religion 9, it's both value total is 9. In case of low response 28 related Hindu religion 111, related Muslim religion is total value 139, in case of average response number of response related with Hindu religion its value 290, in case of high response the number of response related with Hindu 127, while 34 related Muslim religion the total value 161, finally in case of very high response the number of response related with Hindu religion equal to 1, while is case of Muslim religion to equal to zero, its total value equal to 1 as the results of the given table of observation we have known that either calculate to value is a row or in a column is total is same (600).

Conclusion: - Polio, short for Poliomyelitis, is a viral disease that can damage the nervous system and cause paralysis. The Poliovirus enters the body through the mouth, usually from hands contaminated with the stool of an infected person. Polio is preventable by immunization. Since Polio immunization has become widespread in the United States, cases of Polio are rare. However, Polio remains a problem in many parts of the word. The number of female respondents is more than male respondents $(318>282)$ either we calculated them in row or column the total value of respondents is equal. We analyze have the given table the number of female respondents as well as these percentage ratios is more than male respondents [317 (52.8) > $283(47.2)]$. In case of average responses areas related with urban is also lesser than rural areas $(132<158)$ as well as in case of high response the number of response related with urban areas is greater than rural areas $(101>60)$ while in case of very high response the number of responses related with urban areas perfectly inelastic it means 
zero. While in case of rural areas equal to 1 . It can be seen that $\chi^{*^{2}}$ (calculated) value has come out to be 113.295 but $\chi_{t}^{2}$ (tabulated) value to be 9.488 since here calculated value is greater than to tabulated value $\left(\chi^{* 2}>\chi_{t}^{2}\right)$ which is significance at $5 \%$ level of confidence therefore null hypothesis is rejected.

\section{Reference:-}

i. Andersen, R.M., Andersen, O.W., (1979) "Trends in the use of health services", in Haward E.F., Sol Livin and Leo Reader (eds) Hand book of Medical Sociology, New Jersy, Englend Cliffs Prentice Hall, Chi-8. 37-91.

ii. Alwin, D.F. and Hauser (1975): The decomposition of Effect in Path Analysis, American Sociological Review Vol. 40 Pp. 37-47.

iii. Aneshensel, C.S. (1992) "Social Stress Theory and Research",Annual Review of Sociology; 18: 15-38.

iv. Aylward, B., J. Bilous, et al. (1997) "Strengthening Routine Immunization Services in the Western Pacific through the Eradication of Poliomyelitis.” The Journal of Infectious Disease, 175 (Supplement 1): S268-S271

v. Berg, M; (1992) "The construction of medical disposals: Medical Sociology and medical problem solving in clinical practice; Sociology of Health and Illness 14:151-80

vi. Bird CE, Conrad P, Frement A, Bird CE, Conrad P. (2000): Handbook of Medical Sociology, Fifth Edition Prentio Hall, New Jersey, pp-1-10.

vii. C.D.C. Progress towards global eradication of poliomyelitis eradication (2002) “MMWR”, 2003; 52: 366-9. viii.Johnson, Allan G. (1995): The Blackwell Dictionary of Sociology: A User's Guide to Sociological Language ix. Seavey, Nina, G (1998) "A Paralyzing Fear" The Story of Polio in America, Oregon Public Broadcasting.

x. Sutter, R.W., Cochi S.L. (1997) "Ethical dilemmas in Worldwide polio eradication programme”, An Journal Public Health, 87: 913-6.

xi. Taylor, CE, Cults, T., Taylor, M (1997) "Ethical dilemmas in current planning for polio eradication”, An Journal Public Health, 87-9-22-5

xii. Mathew JL, Babbar H, Yadav S (2002) "Department of Paediatrics”, Maulana Azad Medical College, Lok Nayak Hospital New Delhi, India.

xiii. Rasania SK, Sachdev, T.(2003) “Department of Community Medicine”, Lady Hardinge Medical College, New Delhi-110001.

xiv. World Health Organization (1999) "Progress towards global poliomyelitis eradication”, Weekly Epidemiological Record 2000; 75:134-143.

xv. Dobrowolsky, Donna. (1999) "Polio", Saskatchewan Awareness of Post Polio Society, Inc, pp22-27

xvi. Johnson, Allan G. (1995) "The Blackwell Dictionary of Sociology”, A User's Guide to Sociological Language (1995)

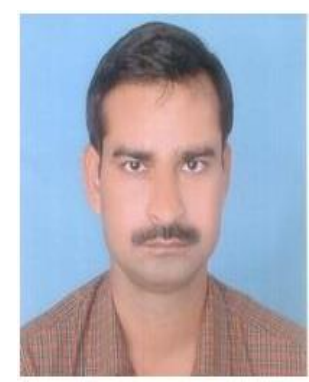

\section{Author Profile}

Dr. Abhimanyu kumar is at present Assistant Professor\& Head of the department of Sociology Govt. P.G. College, Ranikhet, and Uttarakhand .He has done his Doctorate from Dr. B.R. Ambedkar University, Agra. He did M.Phil, M.Sc Agriculture Botany, M.A. Sociology NET -UGC and SLET HPPSC). Has 35 research papers published in international research journals. 